\title{
ESTOCOLMO 2030 E A SUSTENTABILIDADE URBANA APLICADA
}

\author{
Eliana Rosa de Queiroz Barbosa
}

RESUMO: Através do presente artigo pretende-se discutir a corrente atual do planejamento urbano em Estocolmo na Suécia, no que se refere ao desenvolvimento urbano sustentável, através da política de planejamento atual da Visão 2030, do Plano Compreensivo e dos casos de Hammarby Sjostad e NorraDjurgårdsstaden, projetos urbanos paradigmáticos na questão da aplicação de conceitos de sustentabilidade aplicada ao meio urbano. Estocolmo, capital da Suécia e uma das mais importantes cidades da Escandinávia, pretende através da política urbana atual recolocar-se no circuito competitivo de cidades europeias e hoje se propõe a ser uma cidade de classe mundial - world class city. Através das diretrizes e desenvolvimento urbano contidas no Plano Visão 2030, esforços estão sendo feitos para assegurar sua competitividade entre outros centros Europeus, atraindo talentos, criatividade e negócios inovadores. Os projetos urbanos são colocados, na visão estabelecida para a cidade, como pontos estratégicos para garantir essas intenções e a atratividade que a cidade se propõe a estimular, abrigando novas atividades econômicas, aumento do turismo e impulsionando tecnologia construtiva "verde "de ponta, como principais diretrizes do plano. O caso de Estocolmo é aqui utilizado como exemplo da corrente atual do planejamento estratégico na Europa e nos Estados Unidos, baseada num binômio Visão e Projetos Estratégicos, onde, como salientam DE MEULDER, LOECKX e SHANNON (2004), Visão é o Projeto de Cidade como Projeto de Sociedade o qual se pretende alcançar e os Projetos Urbanos são as ações necessárias para tanto. Para a abordagem da questão propõem-se uma análise das estratégias recentes de planejamento e promoção e projetos urbanos na cidade. A pesquisa foi desenvolvida através da análise da documentação do planejamento sueco e entrevistas em profundidade com os principais atores envolvidos com o planejamento urbano de Estocolmo, nos meses de abril e maio de 2011.

Palavras Chave: Estocolmo. Projetos Urbanos. Sustentabilidade Urbana.

UMA ESTOCOLMO DE CLASSE MUNDIAL - “A WORLD CLASS STOCKHOLM”. 
O arrojado slogan já diz tudo: Estocolmo está a procura de melhorar seu posicionamento global e o planejamento urbano é anunciado e utilizado como uma parte importante da estratégia, numa agenda de desenvolvimento de cunho econômico e claramente neoliberal, onde a principal preocupação é "atrair talentos" e criatividade para gerar crescimento econômico.

Aproximadamente $25 \%$ dos habitantes do país vivem na região de Estocolmo, que concentra cerca de 33\% do PIB sueco. Dessa forma, a cidade é considerada "o motor do crescimento Sueco" (LINDER, 2011). A cidade - não apenas a capital, mas o maior aglomerado urbano do país - possui hoje cera de 750 mil habitantes e as 23 cidades que formam sua região metropolitana somam 1,8 milhões de habitantes.

Para garantir o crescimento econômico almejado, a região espera um crescimento demográfico de cerca de 600 mil habitantes até 2030, um crescimento de $15 \%$ da população por década, número bastante otimista considerando as médias de crescimento recentes das cidades europeias.

Como afirma Göran Cars (2011), planejamento urbano na Suécia foi tradicionalmente uma parte importante do modelo de bem-estar social do país, especialmente no que envolve as políticas de habitação pública e seus subsídios. Entre três esferas do planejamento - Nacional, Regional e Local, cada uma com seu órgão específico para tratar do planejamento urbano - existem relações hierárquicas onde a esfera Nacional determina as principais diretrizes e políticas urbanas, enquanto as esferas Regional e Local propõem e desenvolvem planos estratégicos que as viabilizam.

A esfera Local, sendo a mais ativa e a que efetivamente possui meios de colocar planos em prática dado que seus instrumentos de política urbana são os únicos compulsórios, possui três tipos de plano:

- O Plano Compreensivo, baseado em Visões para a cidade, cobrindo a área do município e promovendo diretrizes para seu desenvolvimento, parte de uma Visão Geral, no caso atual a Visão 2030. 
- O Plano Programático, que possui diretrizes para o desenvolvimento a nível distrital,

- O Plano Detalhado, que é compulsório e detalhado, contendo as regulações de uso e ocupação do solo.

O município, dentro desse contexto, possui papel decisivo no desenvolvimento urbano, já que é em sua instância, dentro da política de planejamento atual que o detalhamento dos planos é obrigatório e os impostos municipais são a principal fonte de financiamento disponível para promover infraestrutura urbana.

Tradicionalmente o processo de planejamento ocorreu de forma impositiva, de cima para baixo, o esquema que atualmente está em processo de mudança, conforme esquema abaixo (Figura 1):

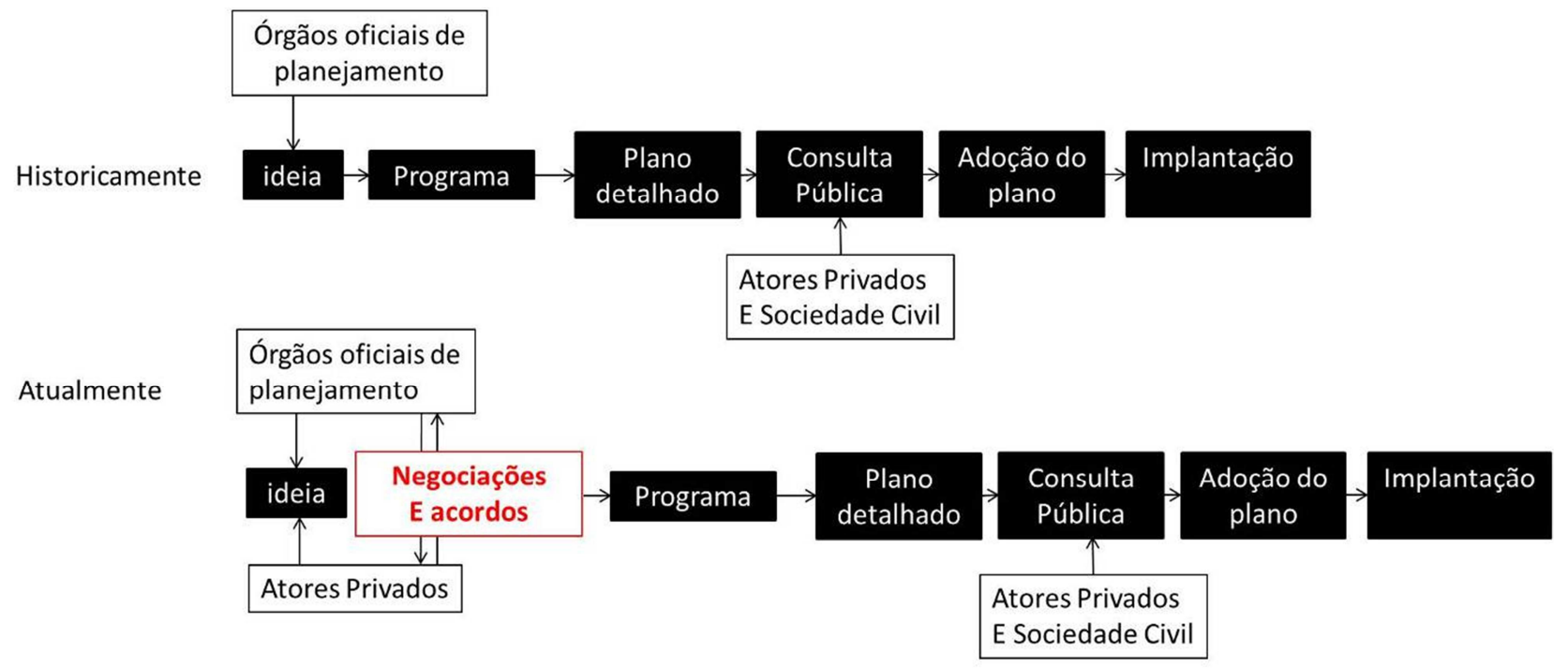

Figura 01: Esquema Processo de Planejamento em Estocolmo. Fonte: autor, 2011.

Essa mudança, de acordo com Cars, deu-se especialmente por uma transformação política, que partiu de posicionamentos políticos sociais-democratas para um arranjo neoliberalista, processo semelhante ao ocorrido por quase toda a europa nos anos 2000. Nesse sistema, novos atores - privados - entraram no processo de tomada de decisão, como o setor imobiliário e os proprietários de terra urbana. O Planejamento 
urbano, dessa forma, está se transformando de uma atividade de responsabilidade do setor público para uma negociação entre diferentes atores, que podem também se envolver no financiamento dessas operações. A principal preocupação hoje, dentro desse cenário mais fluido de tomada de decisão política, é assegurar que a eficiência e a democracia não sejam prejudicadas.

Os debates sobre planejamento urbano da Suécia hoje abordam os papéis das diferentes escalas - Nacional, Regional e Local - na produção das cidades. Novos modos de participação pública e parcerias público-privadas estão emergindo e, afora esses debates, existe um consenso sobre uma necessária mudança das estratégicas de crescimento: da provisão de infraestrutura para o investimento em cultura e atração e criatividade.

\section{ESTOCOLMO: VISÃO 2030}

A política urbana em vigência de Estocolmo foi lançada em 2008 com a aprovação do plano Compreensivo pela Câmara Municipal, que está resumido no documento 'Visão 2030', disponível em diversas línguas de forma a explicar as políticas urbanas de atração - de áreas voltadas à criatividade e inovação - não só para empresas suecas, mas para empresas de todo o mundo que tenham a intenção de estabelecer sua sede na cidade.

Como parte dessa Visão, foram escolhidos pontos focais, formando um esquema urbano de múltiplas centralidades - configurando um anel de projetos urbanos (Figuras 2 e 3) - onde as atividades econômicas e novos empreendimentos privados de habitação deverão acontecer. Com o tempo cada uma dessas áreas receberá um Plano Detalhado desenvolvido pelo departamento municipal de planejamento. Apesar de, desde 2008, a crise econômica mundial ter transformado o caráter inicial de algumas dessas áreas, busca-se coerência entre o Plano Compreensivo e os Planos Detalhados, para que se alcancem as metas gerais para 2030. 

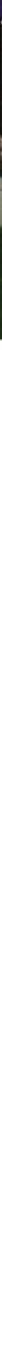

Figura 02: Visão 2030 e o anel de Projetos urbanos. Fonte: Prefeitura Estocolmo. Visão 2030, 2011.

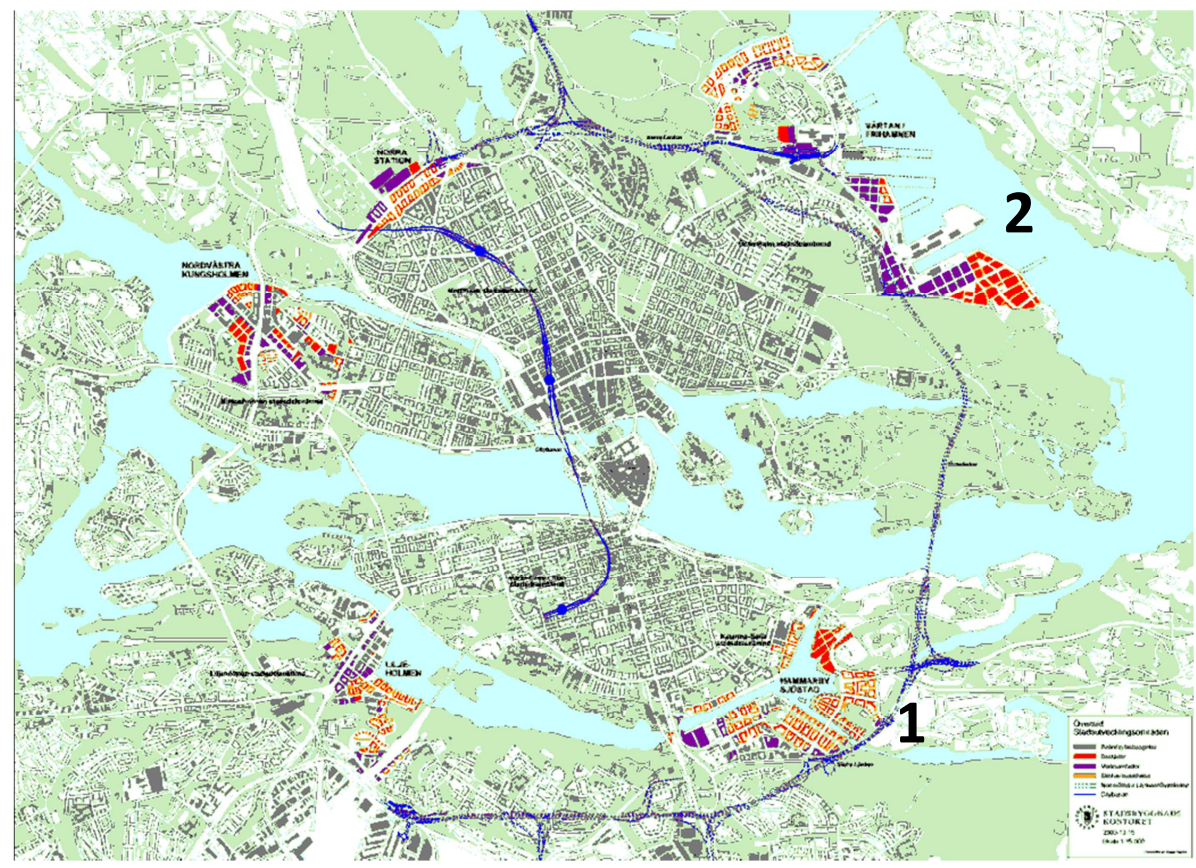

Figura 03: Malha Urbana de Estocolmo salientando os novos grandes projetos, sendo 1 Hammarby Sjostad e 2 o projeto chamado NorraDjurgårdsstaden. Fonte: Prefeitura Estocolmo. 2011. 


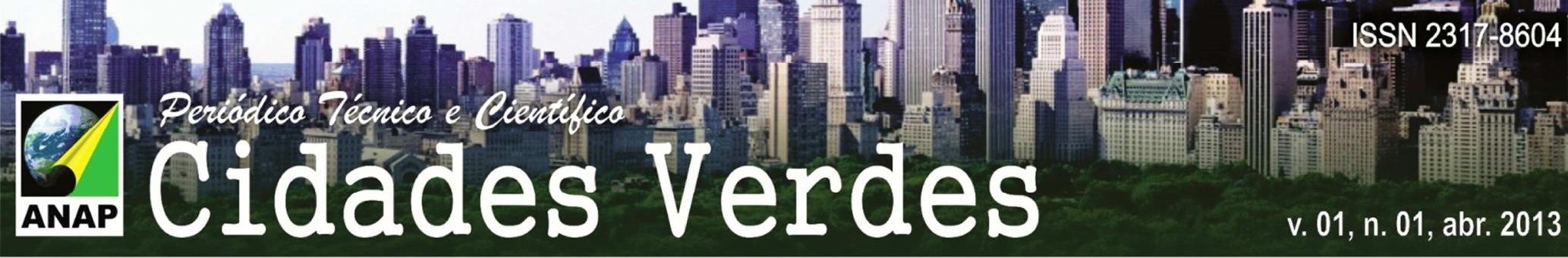

Dessa forma, algumas estratégias são traçadas para contribuir no processo de atração - "city marketing" - e coloca-se um importante papel nos Projetos Urbanos e, principalmente, dos Projetos Urbanos com foco na sustentabilidade ambiental e em estratégias de adaptação climática.

A Visão 2030 estabelece diretrizes gerais para os projetos urbanos a serem implantados, de forma que se tornem complementares e que propiciem o adensamento da malha urbana existente - já apoiada por infraestrutura - de forma que se evite o crescimento horizontal da cidade. A intensão é promover o adensamento da cidade sem expandir a malha urbana, configurando um verdadeiro desafio, pois é importante manter as características atuais da cidade, como salienta Ackelman (2011), preservando a proporção dos elementos urbanos como se observa hoje: um terço verde, um terço água e o restante composto pelos espaços construídos, equilibrando sua particular paisagem urbana.

São ao todo 21 projetos urbanos de diferentes escalas, que envolvem iniciativas de aumento e reconfiguração dos espaços públicos, criação de infraestrutura voltada para mobilidade, educação e tecnologia, turismo, além de grandes projetos urbanos de caráter transformador, envolvendo programas mais amplos e obrigatoriamente mistos.

Dessa forma, foram escolhidas para desenvolvimento e implantação dos grandes projetos seis áreas adjacentes à malha urbana consolidadas, territórios pós-industriais em processo de transformação e que permitissem a densificação, dotadas de infraestrutura existente, nos quais estabelecer uma relação com a água e o verde fosse possível.

Os exemplos a serem abordados, Hammarby Sjostad e NorraDjurgårdsstaden, são projetos paradigmáticos no que diz respeito a busca de um desenho urbano "verde" e o desenvolvimento urbano ambientalmente sustentável, principal argumento a fim de garantir a atratividade desejada.

\section{Hammarby Sjostad - o distrito teste.}

O desejo de Estocolmo de se tornar a capital mundial verde vem desde meados da década de 1990, quando a cidade iniciou sua preparação para concorrer às 


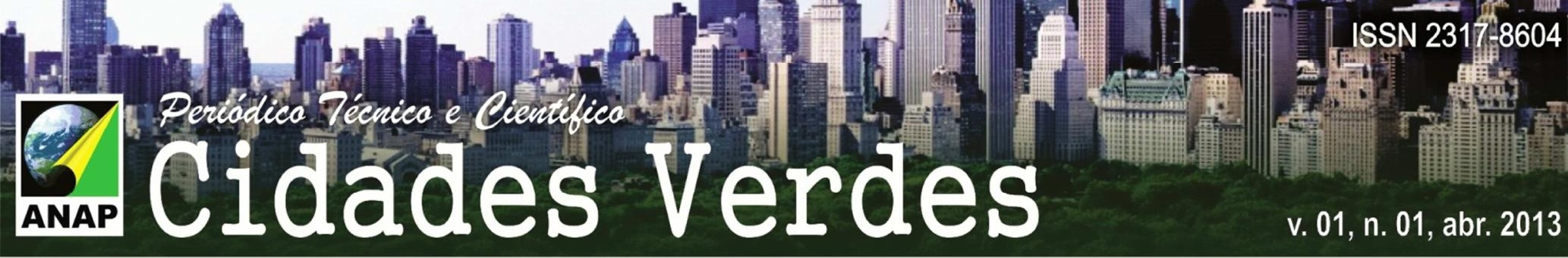

Olimpíadas de 2004. No plano realizado em 1996, o projeto urbano para o distrito de Hammarby Sjostad foi concebido com a finalidade de se tornar a Vila Olímpica, de modo que incorporasse parâmetros urbanísticos e elementos urbanos que o tornassem um distrito que "demandasse o mínimo possível de recursos naturais, que fosse adaptável ambientalmente, um distrito de primeira linha em sustentabilidade urbana em áreas de alta densidade" (Cidade de Estocolmo, 1996, p. 4), incorporando diretrizes estabelecidas na AGENDA 21 (ONU, 1992) e em relatórios anteriores que tratam de metas ambientais (UN Brundtland Report (World Commission on Environment and Development 1987).

O objetivo principal - tornar o distrito ambientalmente sustentável - foi essencial para o desenvolvimento da área e orientou o processo de projeto, impactando no desenho urbano e lidando com aspectos como o modelo de transporte, consumo e produção de energia, produção e gerenciamento do lixo, reuso de água, entre outros. A iniciativa fez parte de um programa integrado de incentivo à política de impactos ambientais na cidade, desenvolvendo novas tecnologias de construção, além de avanços projetuais no que se refere à forma urbana.

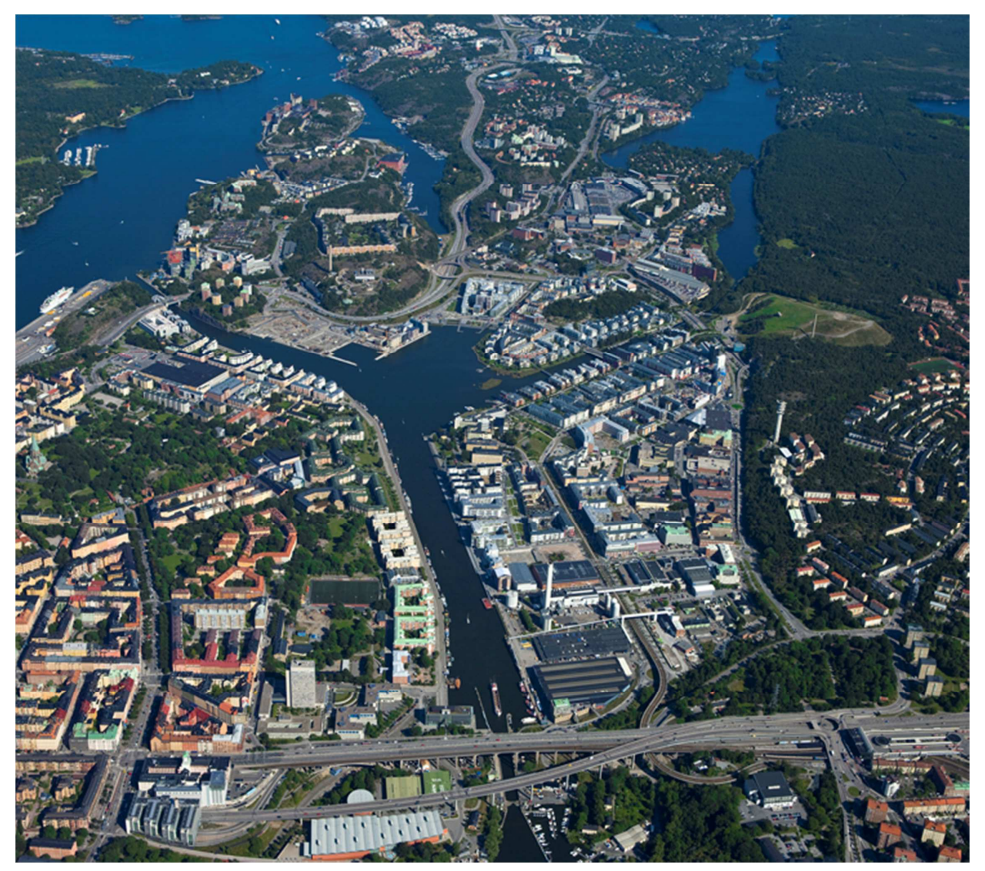

Figura 04: Vista aérea do distrito de Hammarby Sjostad . Fonte: Prefeitura de Estocolmo, 2012. Disponível em: http://bygg.stockholm.se/hammarbysjostad, 2011. 


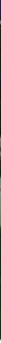

A busca por se tornar um distrito sustentável também orientou a elaboração do programa, cujo objetivo envolvia a oferta de habitação acessível, mistura de usos e a diversidade, que seria alcançada através da um equilíbrio entre unidade privadas e unidades alugadas, habitação estudantil, entre outros. Já para garantir o uso misto a prefeitura chegou a oferecer subsídios de isenção de aluguel para os primeiros comerciantes se instalarem, além de exigir que todos os edifícios possuíssem o térreo com uso comercial voltado para a rua.

Assim, o projeto (Figuras 4, 5 e 6) foi elaborado em área que engloba 200 hectares, com um programa composto por nove mil unidades habitacionais, almejando alcançar uma população de vinte mil habitantes, oferecendo $200.000 \mathrm{~m}^{2}$ de áreas comerciais, com potencial para atrair cerca de 10.000 novos postos de trabalho para a área.

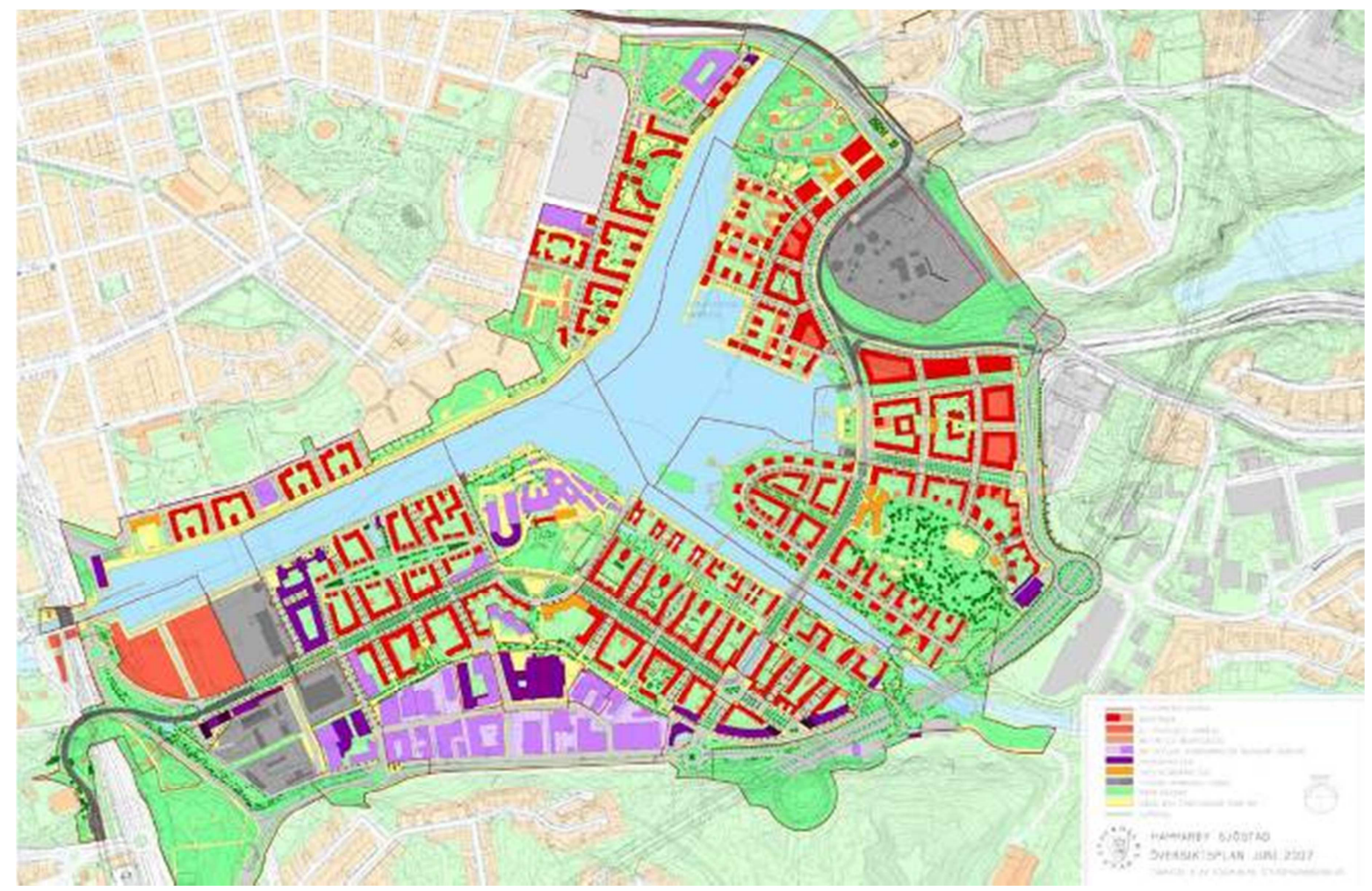

Figura 05: Plano Hammarby Sjöstad. Fonte: Prefeitura de Estocolmo, 2007. 

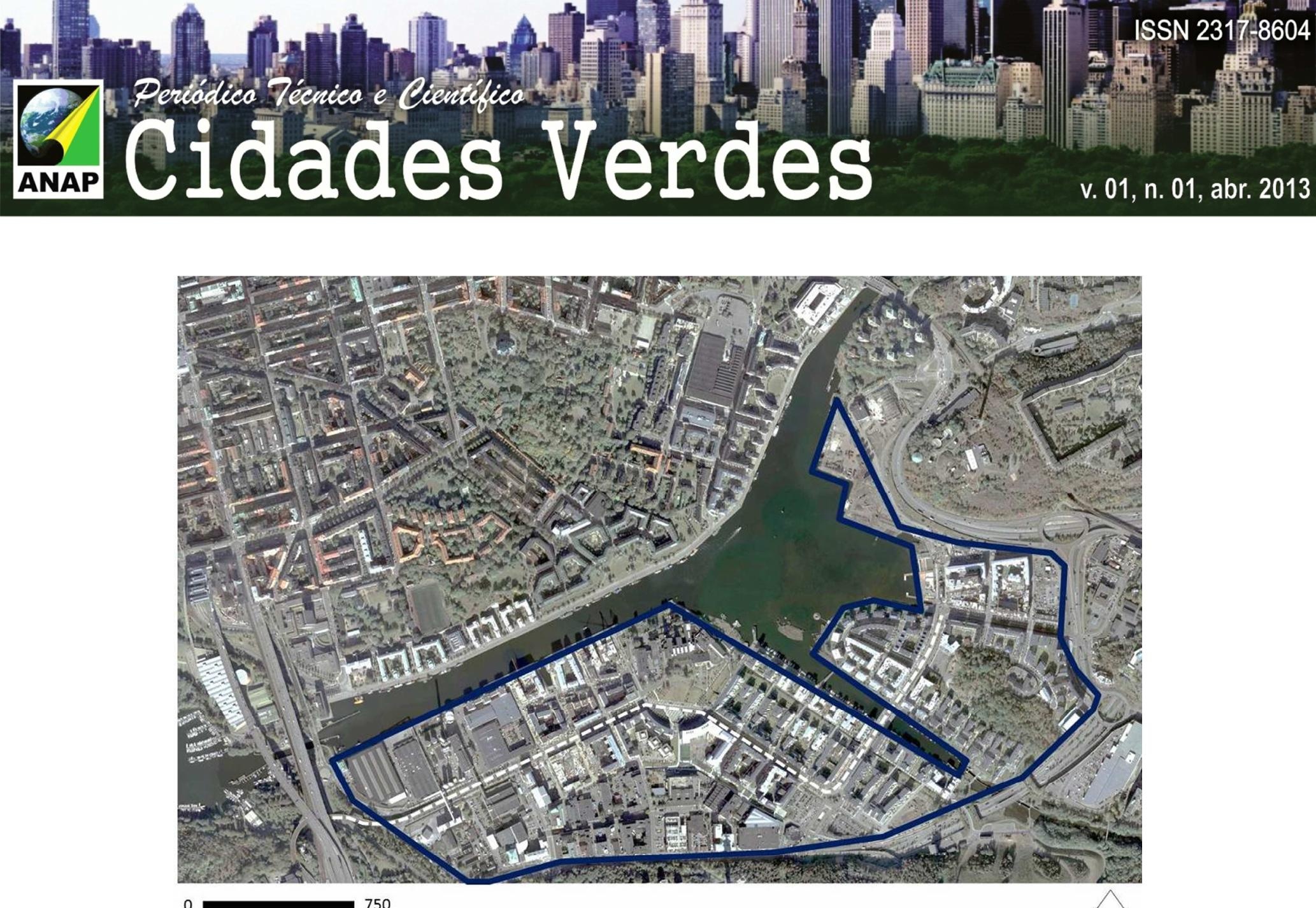

Figura 06: Hammarby Sjöstad foto aérea. Fonte: Google Earth, 2007.

Como projeto piloto de distrito sustentável para a cidade, o processo de planejamento, projeto e contratação dos empreendedores foi liderado e acompanhado de perto pelo departamento municipal de planejamento, a fim de garantir que as metas ambientais fossem alcançadas.

O plano foi concebido levando em conta o que Newmann (1998, p. 3) chama de modelo de metabolismo expandido. De acordo com o modelo, tão sustentável é um assentamento quanto menos consome recursos, menos produz resíduos, não prejudicando sua habitabilidade, comparando o processo de desenvolvimento e produção da cidade ao processo metabólico existente na biologia (Figura 7). Dessa forma, o projeto de distrito sustentável foi pensado de forma que o gerenciamento do uso de energia, água e de resíduos, minimizassem o consumo de recursos para sua produção e operação, bem como a produção de resíduos de todo o processo. 


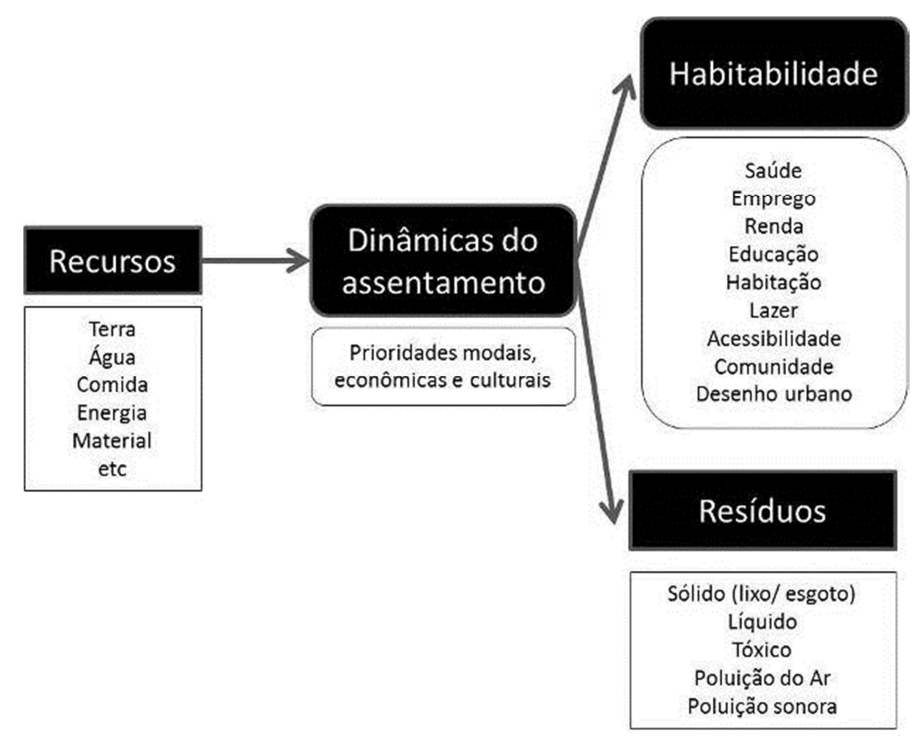

Figura 07: Modelo de Metabolismo expandido para cidades. Fonte: Newmann, 1998.

O objetivo foi criar um distrito residencial baseado no uso de recursos sustentáveis, de baixo consumo e máximo rendimento, elevando ao máximo o reuso e a reciclagem, formando um "ciclo fechado", resumido na figura a seguir:

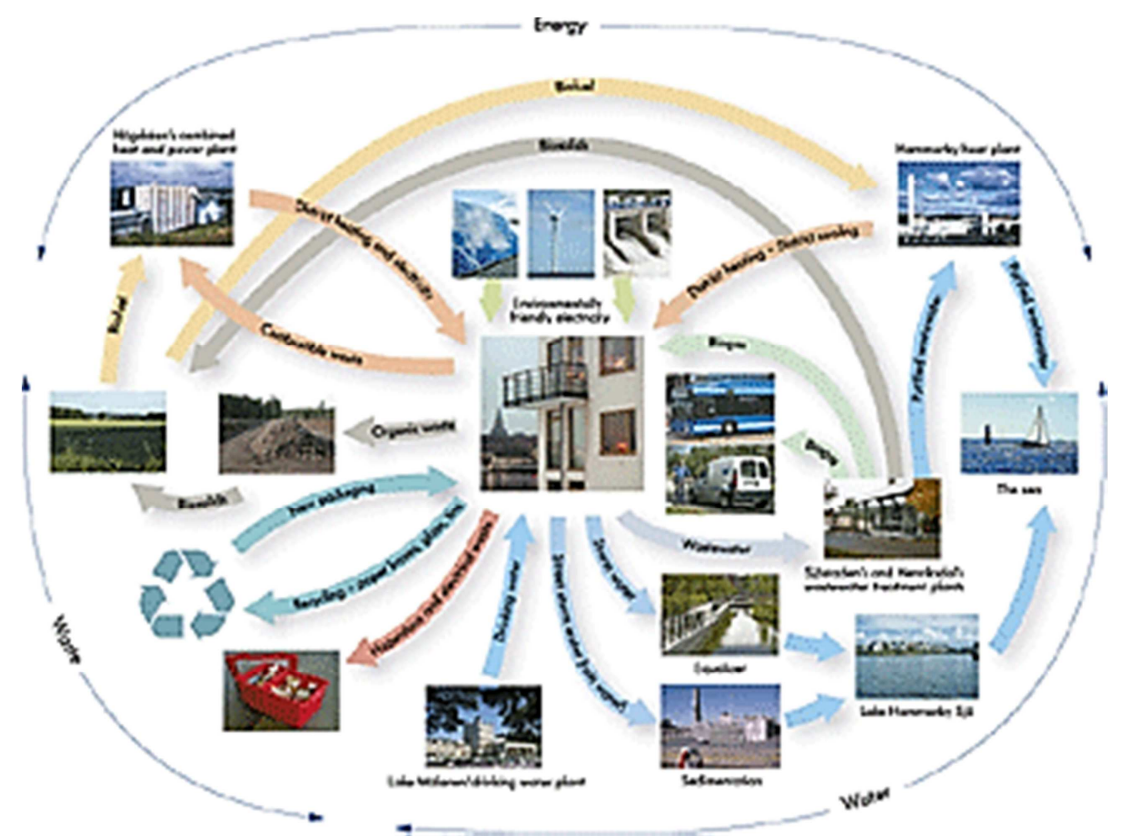

Figura 08: Modelo Hammarby. Fonte: Prefeitura de Estocolmo, 2006. Disponível em: http://www.hammarbysjostad.se/ 
As metas ambientais elaboradas para o plano inicial ditavam que o projeto deveria ser $50 \%$ menos impactante nas emissões de CO2 que projetos a ele contemporâneos na cidade, divididas nas seguintes categorias:

- Uso do solo - descontaminação do solo, reuso e transformação de área pósindustrial em áreas residenciais e espaços públicos.

- Energia (Figura 11) - promoção de fontes de energia renováveis, edifícios com baixo consumo de energia e reuso de resíduos sólidos, produtores de energia.

- Água e esgoto (Figura 11) - promover um sistema o mais limpo possível, tanto no recurso que consome quanto no resíduo que gera, promovendo novas tecnologias de reuso e tratamento de águas pluviais e tratamento de esgoto doméstico.

- Resíduos (Figura 09) - promover a separação do lixo no local de forma prática, possibilitando a reciclagem de material e produzindo energia e aquecimento através da sua combustão no próprio local.

- Transportes (Figura 12) - Implantação de transporte público rápido e agradável, combinado com um sistema de empréstimo rotativo de carro ("Car Pools") e ciclovias, a fim de reduzir o uso do automóvel particular.

- Materiais de construção - Uso de materiais de baixo impacto ambiental, que contribuam com o sistema proposto para a produção de energia, captação de água, etc.

Alguns exemplos de como essas metas foram integradas ao projeto podem ser encontrados nas imagens a seguir: 


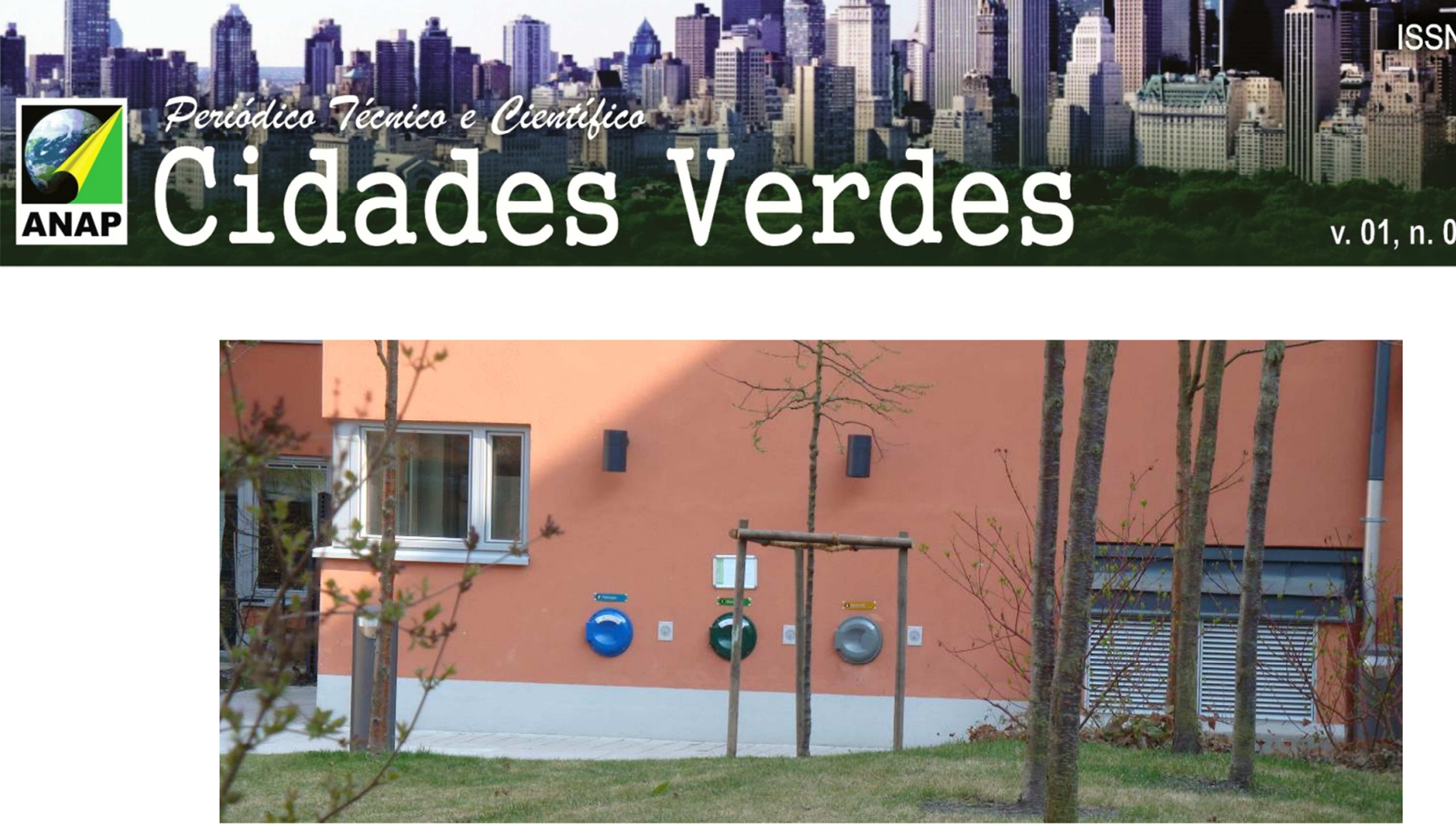

Figura 09: Sistema de Coleta Seletiva do lixo integrado à arquitetura. Fonte: Imagem do autor, 2011.

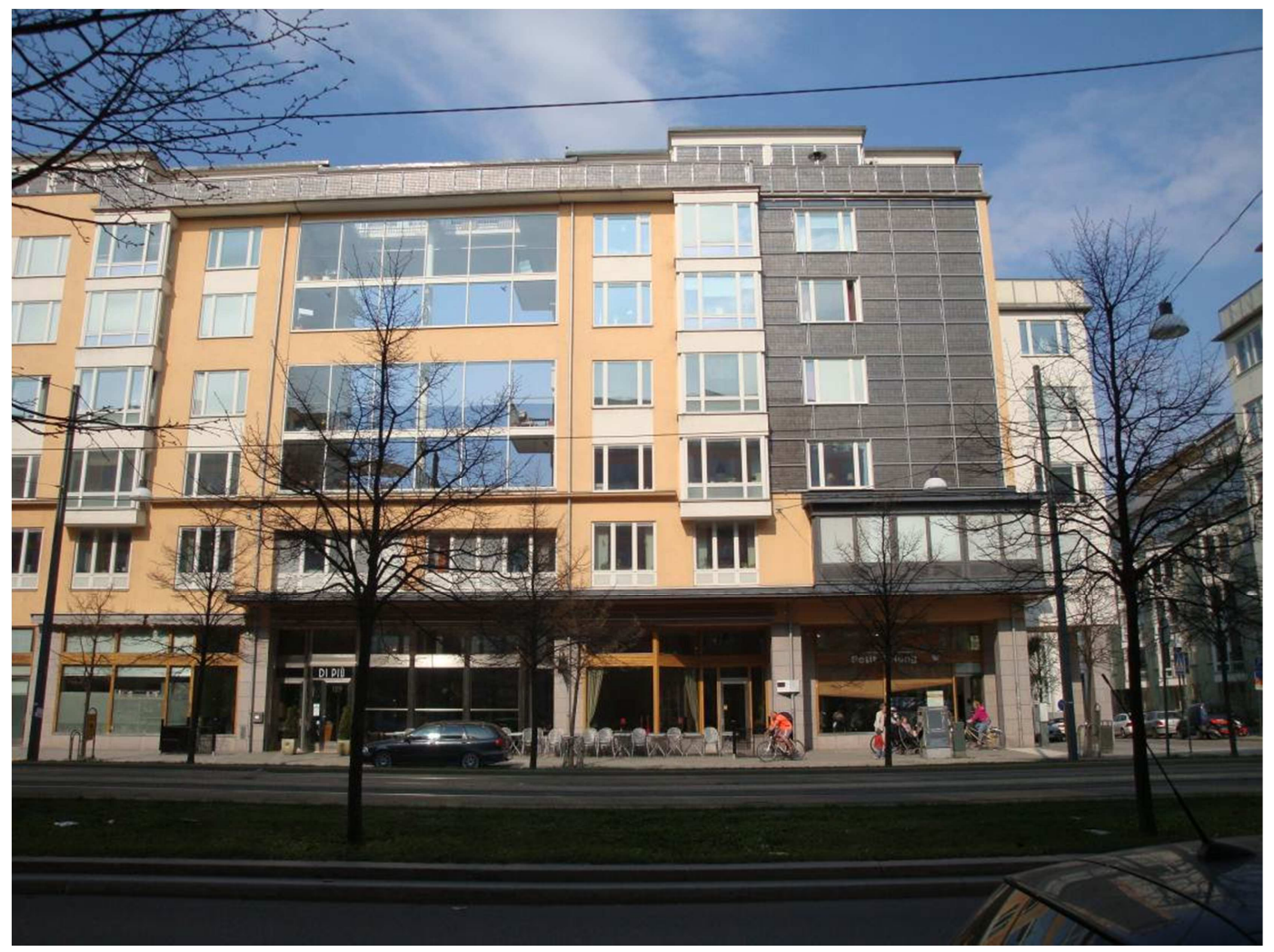

Figura 10: Tratamento de fachada com placas solares exemplificando o sistema de captação da energia integrado à arquitetura no eixo de misto maior densidade (tipologias de térreo comercial mais 7 pavimentos) ao longo da linha de VLT criada. Fonte: Imagem do autor, 2011. 

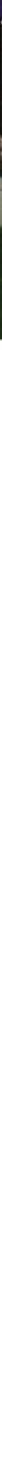

Figura 11: Sistema de espaços públicos que recolhem e abrigam as águas pluviais para posterior tratamento e uso nas áreas de menor densidade (tipologias de térreo comercial mais 3 pavimentos). As áreas livres e o percentual de aberturas foram alculados para maximizar a incidência de sol no verão. Fonte: Imagem do autor, 2011.
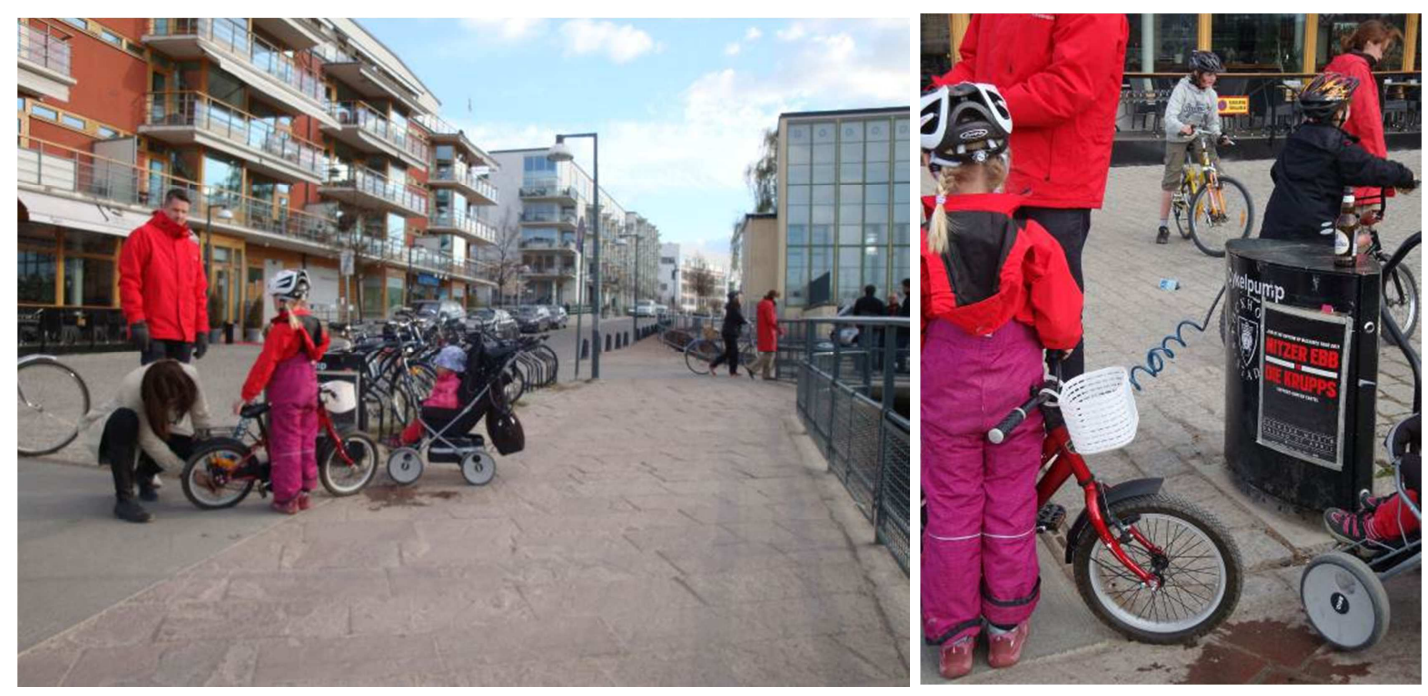

Figura 12: 0 percentual de área para pedestres nos espaços públicos é maior do que em outras áreas da cidade. Infraestrutura urbana que incentiva o uso da bicileta foram espalhas, como pequenos postos de calibragem, como visto acima. Fonte: Imagem do autor, 2011. 


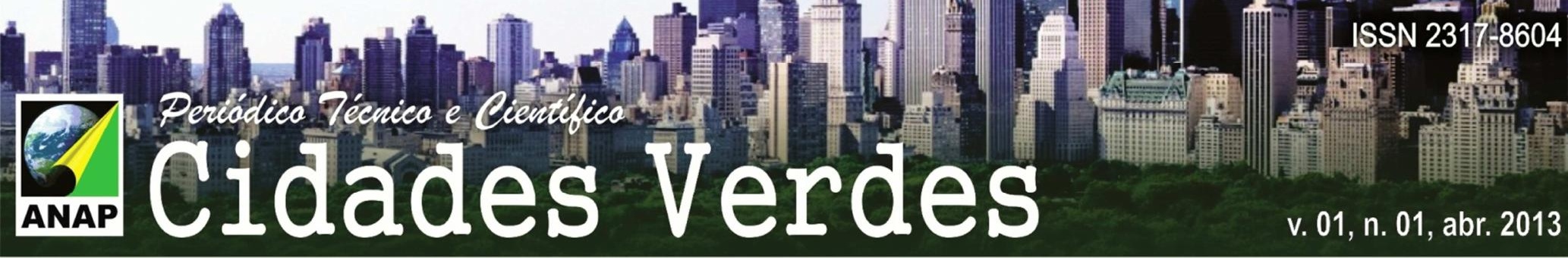

\section{NORRADJURGÅRDSSTADEN - UM DISTRITO DE CLASSE MUNDIAL.}

A projeto urbano NorraDjurgårdsstaden, chamado de Porto Real também é caracterizado como um distrito sustentável. Através da leitura do Plano Detalhado, elaborado para a área em 2010, é possível afirmar que se pretende criar tecnologias de ponta no que se refere à sustentabilidade ambiental, promovendo inovações nas áreas de desenho urbano, infraestrutura urbana e arquitetura, possibilitando a consolidação da cidade como a Capital Verde Europeia, apoiando o marketing da tecnologia ambiental de ponta sueca e contribuindo para o desenvolvimento contínuo de novas tecnologias, que beneficiará, no futuro, todo o setor de construção no país, com metas bastante ousadas como ser adaptável às mudanças climáticas e ser independente de combustíveis fósseis até 2030, 20 anos antes da meta estabelecida para o restante da cidade.

Para que seja possível alcançar essas metas os esforços foram concentradas em produzir e desenvolver tecnologia em cinco áreas:

- Consumo e eficiência energética,

- Transporte Sustentável,

- Adaptações para mudanças climáticas,

- Modelos de ciclos ecológicos

- Transformações culturais e de modo de vida

Novos parâmetros e indicadores estão sendo estabelecidos, além de tecnologias de monitoramento e avaliação para que seja possível medir com mais eficiência a produção dos resíduos sólidos, consumo energético, além do desenvolvimento de técnicas do gerenciamento de mobilidade, de modo a melhorar o "modelo verde" já implantado no projeto urbano Hammarby Sjostad. Coerentemente com o depoimento de Goran Cars (2011), o departamento de planejamento está atualmente envolvendo os empreendedores nos estágios iniciais do processo de tomada de decisão do Plano Detalhado (Figura 13), para melhorar as chances de se alcançar as metas ambientais. É importante notar o destaque para o fato de flexibilidade ser considerada crucial, já que o plano deve ser adaptável às transformações e avanços na tecnologia da construção, devendo dessa forma as políticas devem ser "adaptáveis". 
Assim como em Hammarby, para possibilitar o desenvolvimento da área, a operação consiste na aquisição de parte da terra pela municipalidade de agentes privados e empresas públicas. Parte da terra já era de posse da cidade de Estocolmo e o processo de gerenciamento no projeto conta com a compra das áreas - já com o novo parcelamento - pela iniciativa privada através de leilões fechados. As empresas vencedoras dos leilões são as que serão responsáveis pela construção definitiva do plano detalhado, num processo de contínua negociação entre a Agência de Pública de Desenvolvimento Urbano de Estocolmo, órgão municipal autônomo responsável pelo gerenciamento do projeto, e o setor privado.

Em entrevista, o responsável pelo departamento de planejamento da prefeitura ao ser questionado sobre a decisão e vender a terra - ao invés de exercer um papel mais ativo no processo de construção e desenvolvimento do projeto, especialmente no que se refere à habitação pública, foi enfático: "vender a terra é uma decisão política", afirmação consistente com a análise do Prof. Cars (2011) que menciona uma mudança, citada anteriormente.

No que se refere ao alcance dos objetivos definidos pelo Departamento de Planejamento, não fica claro nos documentos oficiais publicados como a negociação entre a Agência e os empreendedores se dá. Quando questionados como é possível garantir o número de unidades habitacionais, a diversidade, e a mistura de usos e de tipologias habitacionais, espaços comerciais e de serviços a serem construídos, o argumento é que o Plano Detalhado é alvo de negociação diária entre a municipalidade e o setor privado, com resultados, como observado em Hammarby Sjostad, coincidindo "cerca de 90\% com o que foi inicialmente definido" (LINDER,2011). 

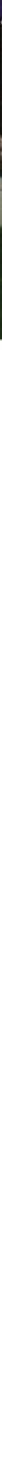

Figura 13: Masterplan da área, demarcando a redefinição do viário e as diferentes características, ocupação, densidades e uso do solo propostos para cada porção do projeto. Fonte: Prefeitura de Estocolmo, 2007.

A necessidade de mudanças, adaptabilidade e fluidez do plano é constantemente salientada, especialmente no que se refere às restrições e especificidades ambientais. Os níveis de pressão sobre os empreendedores, argumenta Ackelman (2011), mudam com o tempo, de acordo com o que se mostra "possível e impossível", sem que se comprometam as metas ambientais. 

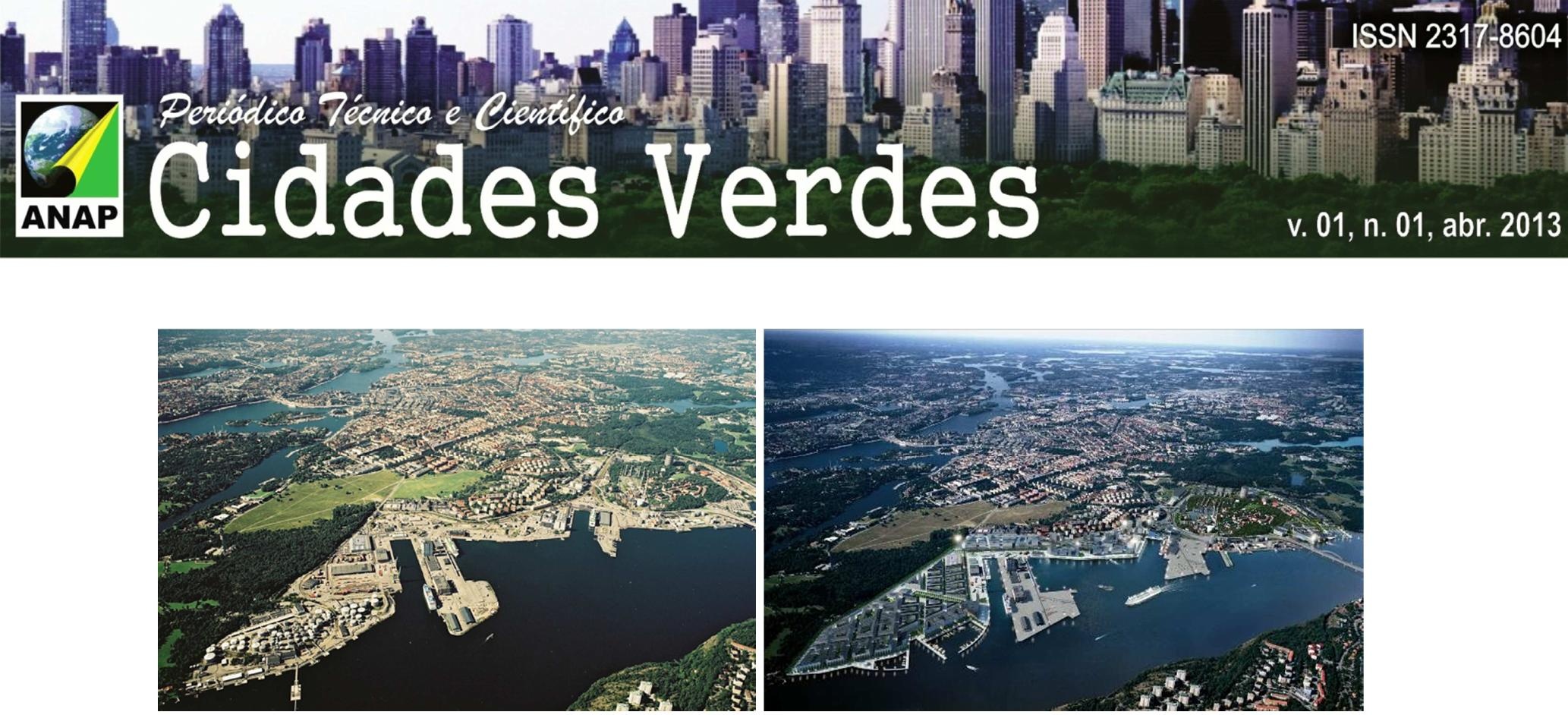

Figuras 14 e 15: Area de NorraDjurgårdsstaden em 2010 e o modelo do projeto com o centro da cidade acima. Fonte: Prefeitura de Estocolmo, 2010.

O projeto abrange 267 hectares (Figuras 13, 14 e 15), com programa que envolve 10.000 novas unidades habitacionais - somando 25.000 novos habitantes - e um montante de área voltada para o setor terciário soma $600.000 \mathrm{~m}^{2}$, que envolveria a geração de 30.000 postos de trabalho. A distância do centro é de 3,4 km e a infraestrutura proposta envolve novas linhas de ônibus movido a biogás, ciclovias, VLT, Metrô e o Terminal de Ancoragem de Cruzeiros da cidade, uma das âncoras do projeto.

Semelhante a Hammarby em seus principais objetivos gerais, apesar das arrojadas metas ambientais, o projeto de destaca pela ênfase na questão da promoção de transformações culturais e de modo de vida e na inclusão do patrimônio industrial.

No quesito das transformações culturais, a participação pública no momento da consulta pública foi essencial e envolveu técnicas inovadoras, além das audiências públicas, como focus groups, entrevistas em profundidade, pesquisa de opinião, passeios e dinâmicas na área com moradores do local e de outras regiões da cidade e monitoramento remoto de comportamento, para que fosse possível estabelecer metas factíveis e melhor moldar as transformações comportamentais almejadas.

Já o patrimônio industrial encontrado, pertencente à empresa municipal de gás e considerado importante marco referencial na paisagem, e parte da identidade da área, foi utilizado como ponto de partida para o Plano Detalhado na primeira área do projeto a ser desenvolvida (Figuras 16 e 17), sendo utilizado como âncora cultural, através de um 


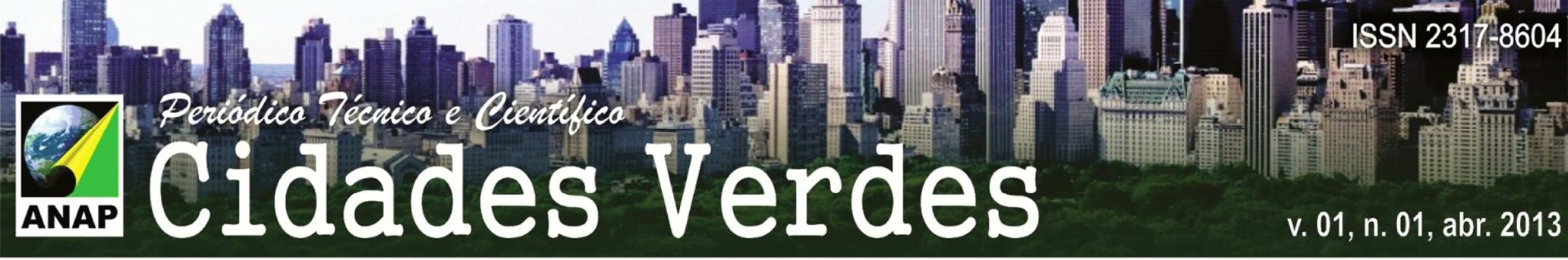

projeto do escritório Herzog \& De Meuron, uma estratégia comum de "city Marketing" frequentemente encontrada nos grandes projetos urbanos europeus.

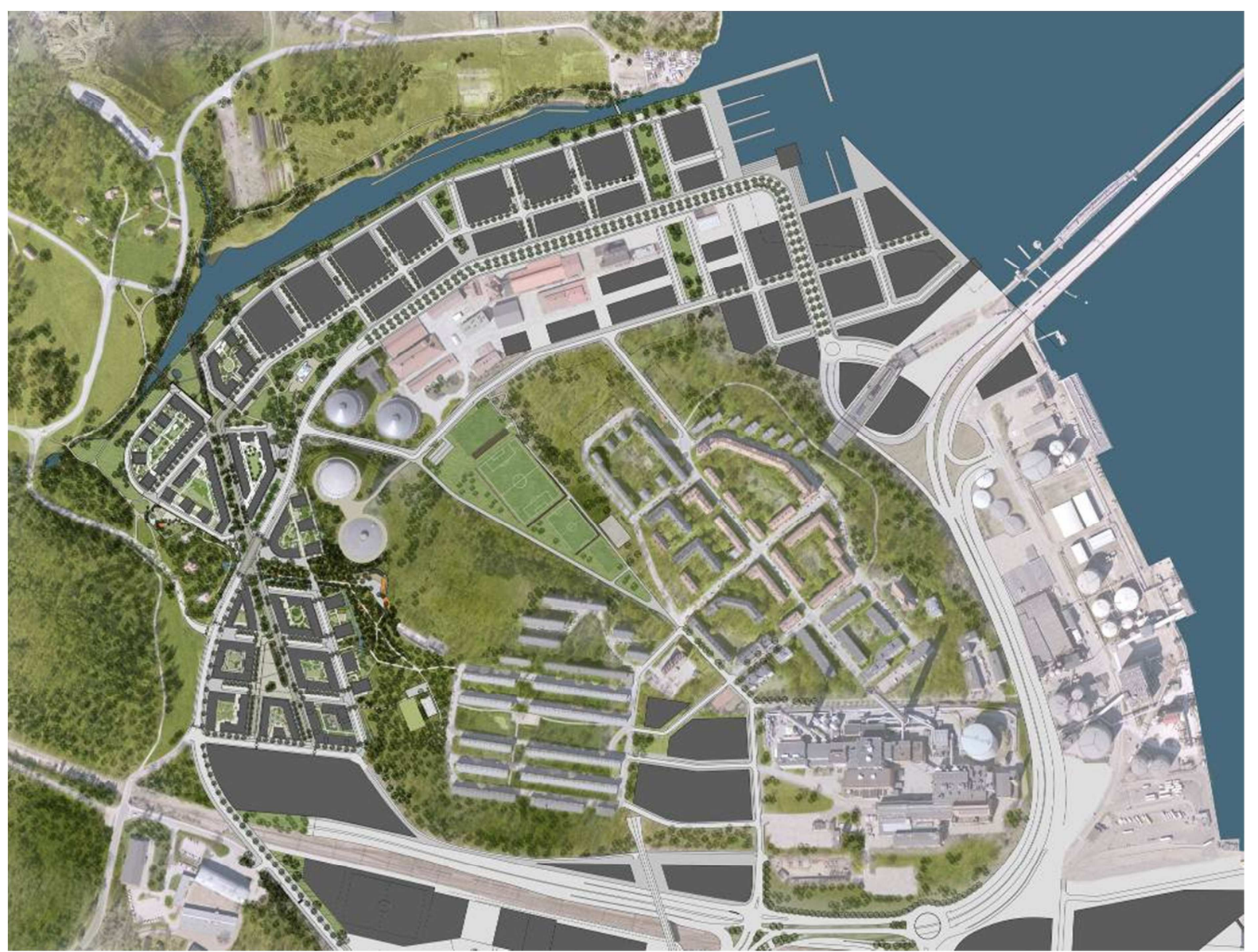

Figura 16: Plano detalhado da área de Hjorthagen, primeira parte de NorraDjurgårdsstaden a ser desenvolvida. Fonte: Prefeitura Estocolmo, 2011. 

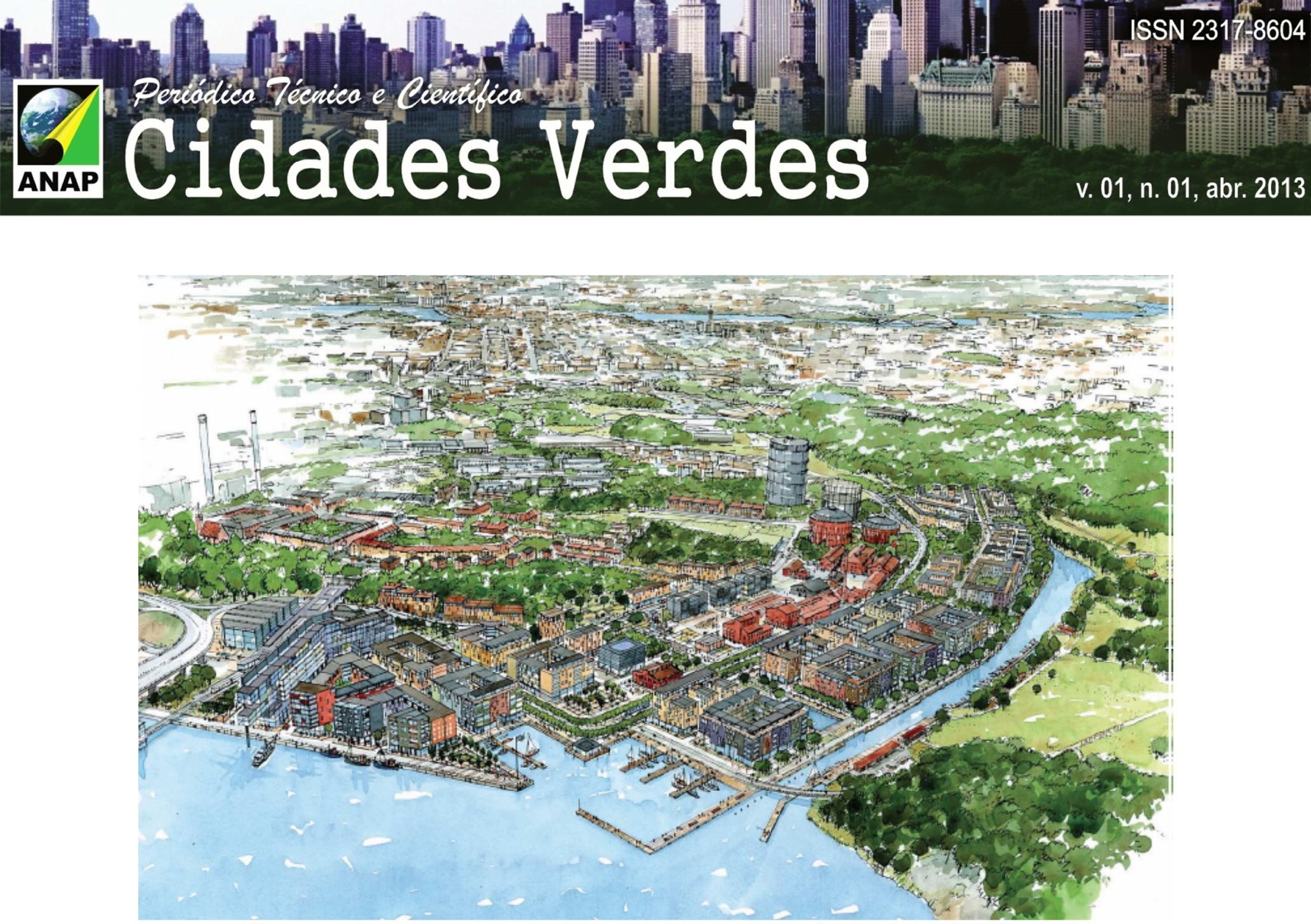

Figura 17: Ilustração da área de Hjorthagen, primeira parte de NorraDjurgårdsstaden a ser desenvolvida. Fonte: Prefeitura Estocolmo, 2011.

O detalhamento do plano se encontra em andamento. O cronograma de implantação envolve a ampliação do terminal de passageiros existente - Porto turístico e a implantação de um centro de entretenimento em suas imediações, aproveitando seu potencial.

O Plano Programático (Visão a nível distrital) demonstra a intenção de transformar a área em uma nova centralidade econômica. O terciário avançado, entretanto, ainda se mostra resistente a deixar a consolidada região central e se deslocar para a área (LINDER, 2011), mas NorraDjurgårdsstaden já conta com edifícios recém inaugurados e certificados pelo selo LEED, na região do Terminal.

Dessa forma, o faseamento da implantação denota a intenção de primeiro oferecer um bairro sustentável de uso misto nos moldes de Hammarby ao norte da área, contando com importante âncora cultural para que sirva de apoio à nova centralidade. 


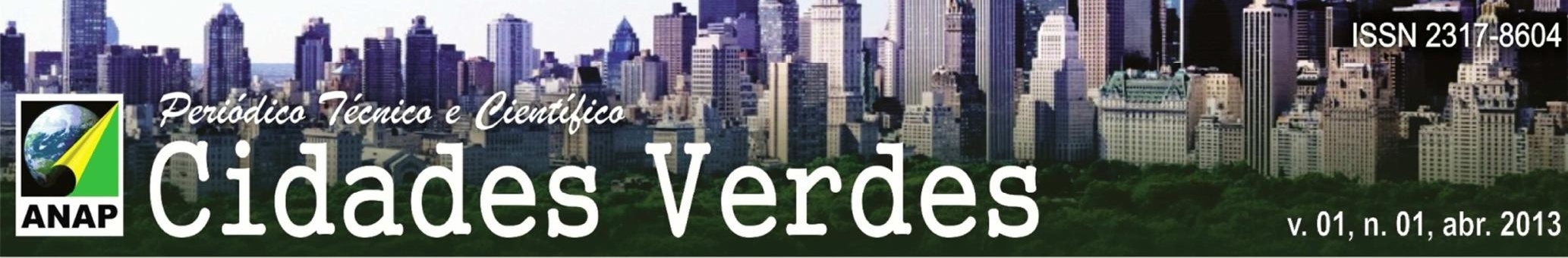

A área que receberá e concentrará o terciário avançado aproveitar-se-á das externalidades positivas trazidas pela primeira fase implantada. Resta saber se todos os atrativos propostos pelo projeto serão suficientes num cenário de estagnação econômica.

\section{CONCLUSÃO}

Os processos socioeconômicos ocorridos no território europeu desde meados da década de 1970 alteraram significantemente a produção e o desenvolvimento de suas grandes cidades. O esvaziamento industrial ocorrido nas cidades europeias a partir da década de 1980 e a necessidade de reconversão de territórios pós-industriais, paralelamente a transformações políticas que possibilitaram maior participação da iniciativa privada no processo de produção da cidade, dadas as transformações do modelo de bem-estar social, acabaram por colaborar pela disseminação de grandes projetos urbanos cuja finalidade é transformar territórios subutilizados, aumentar a densidade demográfica de áreas dotadas de infraestrutura integradas à malha urbana existente, atrair atividades econômicas contemporâneas, inovação e criatividade.

Nesse contexto a cidade de Estocolmo a partir de meados da década de 1990 passa a desenvolver projetos urbanos, projetados pela municipalidade, baseados na aquisição de terra urbana e posterior oferta de oportunidades de projetos a serem desenvolvidos pelos atores privados, cujos parâmetros urbanísticos seguem estritamente o plano inicial da prefeitura.

Os projetos de Hammarby Sjostad e NorraDjurgårdsstaden são exemplos dessa política que se utilizam do desenvolvimento urbano sustentável como principal fator de atratividade, parte de sua estratégia de atração, fato confirmado pela eleição da cidade como Capital Verde da Europa em 2010, graças ao projeto Hammarby Sjostad e salientado no plano para NorraDjurgårdsstaden, cujo objetivo seria de consolidar a posição da cidade como líder em desenvolvimento de tecnologia verde (Visão 2030. Fonte Prefeitura de Estocolomo, 2011).

Ambos os projetos estudados vem contribuindo para o aprimoramento de tecnologias ambientalmente sustentáveis aplicadas ao desenho urbano, aliando 


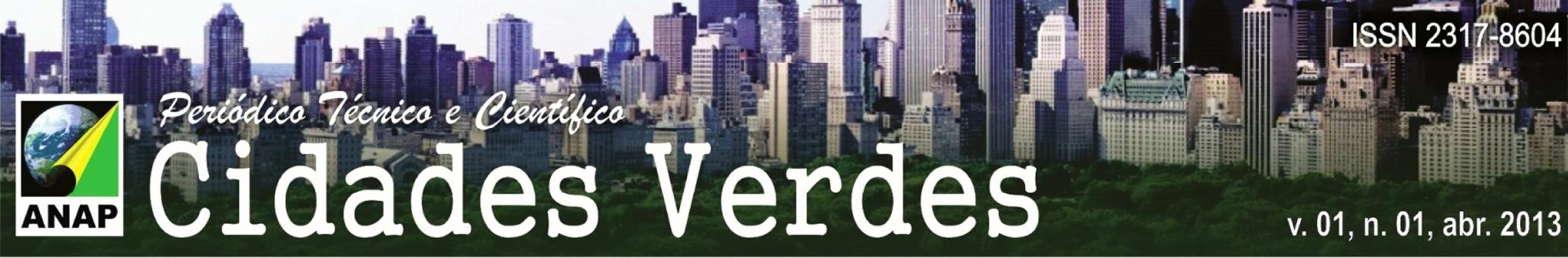

desenvolvimento imobiliário e a criação de conhecimento através de parcerias com universidades locais, além de incentivos para o estabelecimento de empresas com esse perfil na cidade.

Percebe-se uma diferença significativa entre os objetivos e o desenvolvimento dos planos para os dois distritos, principalmente após 2008 com o advento da crise mundial econômica. Inicialmente, em Hammarby, a necessidade de atração de novas atividades econômicas para a cidade não foi tão enfatizada. O distrito possuía certo equilíbrio de usos em seu programa. Já no Porto Real, a existência de grandes âncoras culturais e turísticas e de um maior percentual do programa voltado para o uso terciário denota a mudança de perfil. Melhorar a viabilidade econômica parece ser uma diretriz importante para o Porto Real para o projeto, portanto o gancho ambiental continuou a ser explorado, entretanto de forma mais agressiva com a finalidade de convertê-lo em agente de crescimento econômico.

Fica claro o papel dos projetos urbanos no desenvolvimento e crescimento da cidade e de sua consolidação como principal cidade escandinava, apoiando-os no desenvolvimento e atração de economia criativa baseada no mercado da tecnologia verde.

Entretanto é cedo para avaliar o projeto. Os recentes desenvolvimentos da crise de 2008 mudaram o cenário de crescimento inicialmente propostos pela Visão 2030 e trazem questionamentos importantes para possíveis futuras pesquisas:

As âncoras culturais e turísticas propostas serão suficientes?

Continuará a iniciativa privada investindo em tecnologia verde para o cumprimento das Metas da Visão 2030, num cenário de estagnação econômica?

Com a transformação do modelo de bem estar-social sueco, como garantir a coesão social na escala do projeto urbano?

Essas questões ilustram o debate hoje acerca dos grandes projetos urbanos no contexto de crise e incerteza do continente europeu, bem como sua relevância para retomar a discussão dos grandes projetos urbanos e da competitividade urbana no contexto brasileiro. Seriam os grandes projetos urbanos "modelo", como os exemplos paradigmáticos europeus, suficientes para solucionar questão urbana no país? 


\section{REFERÊNCIAS}

BARBOSA, Eliana R.Q.; CAIELLO, Simone; DORRIAN, Andrew (et all). Assuring an economic viable project for all the stakeholders at NorraDjurgårdsstaden.. EUROPEAN SPATIAL DEVELOPMENT AND PLANNING NETWORK INTENSIVE PROGRAMME 2011. KTH, Estocolmo, 2011. Disponível em: http://esdp-network.eu/attachments/File/IP-2011/Students reports/Report EconSust1.pdf. Acessado em $\underline{20 / 10 / 2012 .}$

CARS, G. (2011), Entrevista realizada em 02/05/2011 na KTH Estocolmo.

COMMISSION FOR ARCHITECTURE AND THE BUILT ENVIRONMENT. 'HammarbySjostad'.2010. Disponível em: http://webarchive.nationalarchives.gov.uk/20110118095356/http:/www.cabe.org.uk/c asestudies/hammarby-sjostad. Acessado em 04/05/2011.

DE MEULDER, Bruno; LOECKX, André; SHANNON, Kelly. "A Project of Projects"em LOECKX, Andre (org.) Urbantrialogues: visions, projects. Localising Agenda 21: Action Planning for Sustainable Urban Development (Program).Bruxelass: UNHabitat, 2004.

DEPARTMENTO DO MEIO AMBIENTE SUECO. New Planning and Building Act. 2010. Disponível em: http://www.sweden.gov.se/sb/d/12872/a/147223. Acessado em 04/05/2011.

EUROPEAN COMMISSION. 'Environment', 2012. Disponível em: http://ec.europa.eu/environment/eussd/ Acessado em 20/10/2012.

LINDER, S (2011), Entrevista realizada em 02/05/2011 na Camara de Comercial de Estocolmo.

MAGALHÃES, Felipe Nunes. Da Metrópole á Cidade-região - Na direção de um novo arranjo espacial metropolitano? Revista Brasileira de Estudos Urbanos e regionais. V 10 (2), nov. 2008. Pág. 9 a 27.

MARCEAU, J. Innovation in the City. Innovative management, policy and practice, 2008. Vol 10, pp 136-145

MUNICÍPIO DE ESTOCOLMO. Planning Permit. 2010, Disponível em: http://insynsbk.stockholm.se/Byggochplantjansten/GallandePlan/Planarende-

Gallande/?JournalNumber=2001-07633\&rid=40034\&flg=0\&plantype=Detaljplan . Acessado em 05/05/2011.

MUNICÍPIO DE ESTOCOLMO. Business and Statistics. 2011. Disponível em:

http://international.stockholm.se/Business-and-statistics/Statistics. Acessado em 04/05/2011.

OLOFSSON. Entrevista em Royal Seaport Authority, Estocolmo 01/05/2011.

SECHI, Bernardo. Primeira Lição do urbanismo. São Paulo: Perspectiva, 2012.

SOMEKH, N. Projetos Urbanos e Estatuto da Cidade: limites e possibilidades.Arquitextos, São Paulo, 097.00, Vitruvius, jun 2008. Disponível em:

http://www.vitruvius.com.br/revistas/read/arquitextos/09.097/131.

SOMEKH, N.; CAMPOS NETO, C. M.. Desenvolvimento local e projetos urbanos. Arquitextos. São Paulo. 059.01, Vitruvius, abr 2005.

http://bygg.stockholm.se/norradjurgardsstaden http://www.vartan.nu/ 